\title{
ANALISIS PERTANYAAN RETORIKA DALAM AYUB 39:16-33
}

\author{
Firman Panjaitan ${ }^{1}$
}

\begin{abstract}
Abstrak
Ayub. 39: 16-33 dihadirkan sebagai jawaban Tuhan terhadap pergumulan dan pertanyaan Ayub. Melalui gambaran-gambaran tentang binatang yang diikuti dengan pertanyaan retorika, maka perikop Ayub 39:16-33 sebenarnya mau menghadirkan sosok Tuhan yang begitu Agung dan sekaligus yang tidak dapat dijangkau melalui pikiran. Kemahakuasaan Tuhan begitu besar dan mistetrius; tetapi bukan berarti tidak berdampak bagi kehidupan. Di dalam kebesaran dan kemisteriusan itulah karya Tuhan selalu mengiringi kehidupan manusia.
\end{abstract}

Kata-kata Kunci: Ayub 39:16-33, Pertanyaan Retorika

\section{Pendahuluan}

Dalam struktur secara keseluruhan, kitab Ayub berisi sebuah prolog/pengantar (psl. 1-2), diikuti dengan beberapa siklus pidato serta "perdebatan" antara Ayub dan ke-3 sahabatnya, yaitu Elifas, Bildad dan Zofar (psl. 3-31), pidato Elihu (psl. 32-37), wejangan/pidato/jawaban Tuhan Allah kepada Ayub (psl. 38-41), pertobatan Ayub (psl. 42:1-6), dan sebuah epilog yang berisi tentang pemulihan keadaan Ayub (psl. 42:7-17).

Secara garis besar, kitab Ayub hendak berbicara tentang kesengsaraan yang dialami oleh Ayub sebagai orang beriman; dan pengalaman kesengsaraan yang dialami Ayub ini tidak mudah untuk dipahami, sehingga muncul pertanyaan besar, "Mengapa orang benar harus mengalami penderitaan?". Kisah ini menjadi lebih menarik ketika masalah penderitaan yang dialami Ayub menjadi bahan yang dipakai oleh ketiga

${ }^{1}$ Mahasiswa Program Doktoral Prodi Teologi Sekolah Tinggi Filsafat Jaffray Makassar. 
sahabat Ayub untuk memperdebatkan pandangan mereka tentang hikmat dan nilai kehidupan. Ketiga sahabat Ayub beranggapan bahwa kesengsaraan Ayub adalah karena dosa yang selama ini sudah dilakukan Ayub; sedangkan Ayub memiliki pandangan lain tentang penderitaan yang dialaminya. Hal ini bisa terjadi karena dalam Perjanjian Lama memang ada dua macam aliran tradisi hikmat, yaitu: ${ }^{2}$

1. Tradisi hikmat yang bersifat keduniawian (biasa disebut dengan tradisi ortodoks), yang dikukuhkan dalam pandangan Theodisi yang mengatakan bahwa Allah mengganjar orang benar dan menghukum orang jahat.

2. Tradisi hikmat yang menekankan bahwa hikmat dan kuasa Allah nyata di dalam karya-karya kreatif Allah (bdk. Yes. 40:12-13, Ayb. 28). Aliran ini menekankan sifat Allah yang transenden dan penuh rahasia dan rasa takut dan gentar dalam diri manusia bila berhadapan dengan kuasa Allah.

Dalam rangkaian kisah perdebatan antara Ayub dengan ketiga sahabatnya, penulis melihat di sinilah letak permasalahan yang terjadi antara Ayub dan ketiga sahabatnya itu. Ada ketegangan yang terjadi dalam cara pandang mengenai hikmat. Di satu sisi ketiga sahabat Ayub menganut pandangan tentang tradisi hikmat yang bersifat keduniawian (ortodoks), sedangkan di sisi lain Ayub memegang pemahaman tentang tradisi hikmat yang kedua, yang menekankan karya kreatif Allah dalam mengatur kehidupan di dunia. Kedua cara pandang ini jelas tidak akan dapat dipertemukan, karena keduanya mengambil jalannya sendiri-sendiri.

Dengan demikian masalah inilah, yaitu perbedaan cara pandang mengenai pemahaman tradisi hikat, yang menjadi isi pokok perbincangan antara Ayub dan ke-3 sahabatnya, di mana ke-3 sahabat Ayub sangat bersikukuh dengan pandangan tradisi hikmat yang bersifat keduniawian, sehingga mereka mendesak agar Ayub mau mengakui dosa yang

${ }^{2}$ Wismoady Wahono, Di Sini Kutemukan (Jakarta: BPK Gunung Mulia, 1987), 232 


\section{Prosiding Seminar Teologi Kitab Ayub}

mengakibatkan penderitaan. Mereka tidak mau tahu tentang paradigma yang dipahami oleh Ayub tentang tradisi hikmat. Mereka memaksakan pemahaman tradisi hikmat ortodoks ke dalam diri Ayub. Hal inilah yang membuat Ayub "cukup kesal" dengan ke-3 sahabatnya, sehingga ia menjuluki mereka dengan para "penghibur sialan" yang hanya menghabiskan omong kosong belaka (lih. Ay. 16:2). ${ }^{3}$

Ungkapan "penghibur sialan” ini sebenarnya memiliki pengertian yang sangat menohok bagi para sahabat Ayub. Karena istilah yang diambil dari kata ' $a m a l^{4}$ (yang berarti miserable; tidak menyenangkan, tidak menghibur) adalah ungkapan yang sangat bersifat antitesis. Seharusnya seorang penghibur bisa menghibur orang yang sedang mengalami kesusahan, tetapi justru "penghibur sialan" adalah orang yang "kelihatannya" berperan sebagai penghibur, tapi dalam kenyataannya merupakan orang yang justru keberadaannya sangat menyudutkan dan senantiasa menghakimi. Keberadaan orang ini sungguh amat menyebalkan dan tentunya tidak akan pernah menjadi berkat.

Karena itu tidaklah mengherankan apabila Ayub menjadikan hal ini sebagai pokok pengaduannya kepada Allah. Dari pergumulan dan perenungan yang berat itulah Ayub mengungkapkan perasaan hatinya kepada Allah (lih. Ayb. 9:32,33; 13:21-23). Apakah Allah itu suatu kuasa misterius yang mencelakakan sehingga Ayub menjadi orang yang terhina dan tidak berpengharapan, ataukah Allah merupakan hakim yang sebenarnya tidak bermakna? Ayub sendiri percaya bahwa Allah adalah hakim yang bermakna, akan tetapi permasalahannya adalah Ayub tidak dapat bertemu dengan Allah dan memperdebatkan perkaranya.

Dalam perenungan yang dikelilingi oleh kebingungan inilah muncul berbagai ungkapan pertanyaan Ayub tentang Allah. Meskipun para

${ }^{3}$ Singgih mengarahkan istilah "penghibur sialan" ini kepada orang-orang yang seharusnya dapat membuat orang susah menjadi terhibur, tetapi ternyata menjadi orang yang melecehkan. Lih. E. G. Singgih, Dua Konteks (Jakarta: BPK Gunung Mulia, 2009), 192.

${ }^{4}$ Benjamin Davidson, The Analytical Hebrew and Chaldee Lexicon (Michigan: Regency Reference Library, 1970), 604. 
sahabatnya (yang menganut paham tradisi hikmat ortodoks) sudah berusaha menyadarkan dan mengarahkan Ayub pada pemahaman ortodoks, namun Ayub tetap bersikukuh dengan pandangannya yang menentang tradisi hikmat ortodoks tersebut. Karena Ayub merasa bahwa ini bukan masalah "benar - salah" yang berakibat pada "berkat - kutuk"; tetapi ada "sebuah misteri Allah" yang sedang bekerja, sehingga Ayub memunculkan pertanyaan-pertanyaan tentang hubungan antara Allah dengan penderitaan yang dialaminya.

Menjawab pertanyaan pergumulan Ayub, Allah menuangkan jawaban-Nya dalam pasal 38-42:1. Secara garis besar Allah ingin menimpali pertanyaan Ayub mengenai, "Mengapa orang benar bisa menderita?" melalui berbagai bukti yang sudah Allah lakukan dalam menciptakan dan memelihara dunia, sehingga melalui bukti-bukti ini Allah hendak mengatakan bahwa keadilan Allah terhadap kehidupan ini seringkali berjalan dalam suasana "misteri" yang tidak mudah untuk dipahami oleh manusia. ${ }^{5}$ Dalam konteks inilah Ayub. 39: 16-33 dihadirkan sebagai jawaban Tuhan terhadap pergumulan dan pertanyaan Ayub.

\section{Ayub 39:16-33}

Ayub 39:16-33 merupakan bagian yang tidak terpisahkan dari 2 wejangan/pidato/jawaban Allah kepada Ayub, seperti yang ditulis dalam pasal 38-41. Masalah yang diperdebatkan Ayub dan ke-3 sahabatnya ditambah dengan pidato Ellihu tetaplah tidak pernah bisa dipecahkan dan memuaskan hati Ayub. Dalam situasi inilah Allah mengungkapkan wejangan/pidato/jawaban-Nya, baik dalam bentuk teguran (yang ditujukan kepada Ayub dan ke-3 sahabatnya) maupun dalam bentuk beberapa pertanyaan yang bersifat retorika.

Adalah menarik ketika mengamati ungkapan-ungkapan pertanyaan retorika Allah. Karena di dalamnya terkandung pemahaman bahwa Allah yang bertanya sekaligus Allah yang menyediakan jawaban

${ }^{5}$ C. Hassel Bullock, Introduction to The Old Testament Poetic Book (Chicago: The Moody Bible Institute, 1979), 106-107. 


\section{Prosiding Seminar Teologi Kitab Ayub}

atas pertanyaan tersebut. Jadi jika Allah mengungkapkan pertanyaan yang bersifat retorika, Allah tidak membutuhkan jawaban dari Ayub karena dalam pertanyaan itulah terkandung jawaban Allah yang hendak membuka mata hati Ayub terhadap eksistensi/keberadaan Allah.

Dalam jawaban-Nya terhadap Ayub, Allah mengajarkan Ayub mengenai karya penciptaan-Nya yang jauh lebih besar dibandingkan keberadaan Ayub; karena Ayub tidak tidak dapat mengontrol setiap kekuatan yang ada di alam semesta ini. Melalui psl. 39-40, Allah berbicara tentang binatang dan burung-burung yang IA ciptakan dan pedulikan/lindungi. Secara khusus, dalam Ayub. 39: 16-33 mau berbicara tentang karya dan perlindungan Allah terhadap beberapa binatang yang disebutkan. Jika mengamati dan meneliti dengan seksama bagian-bagian dari Ayub. 39: 16-33, maka perikop ini dapat dibagi menjadi 4 bagian, antara lain:

1. Ayub 39:16-21 = gambaran tentang burung Unta.

2. Ayub 39:22-28 = gambaran tentang Kuda

3. Ayub 39:29 = gambaran tentang burung Elang

4. Ayub 39:30-33 = gambaran tentang burung Rajawali

Ke-4 bagian ini memiliki pengertiannya masing-masing. Dan dalam setiap bagian terdapat pertanyaan retorika Allah yang mau menjelaskan kedalaman eksistensi Allah yang berkuasa atas segala ciptaan. ${ }^{6}$ Jika dalam bagian ini Allah menggunakan karakter burung dan binatang untuk memberikan jawab terhadap Ayub, maka tujuannya adalah untuk, “... memberi kita akal budi melebihi binatang di bumi, dan hikmat melebihi burung di udara." (Ayub. 35:11), yang memiliki kesejajaran dengan ungkapan Ayub dalam Ayub. 12:7, “Tetapi bertanyalah kepada binatang, maka engkau akan diberinya pengajaran, kepada burung di udara, maka engkau akan diberinya keterangan."

Hal ini menyiratkan pesan bahwa apa yang diperingatkan Allah melalui gambaran karakter hewan ini adalah merupakan pesan bahwa

${ }^{6}$ R. E. Harlow, Job Had A Problem (Canada: Everyday Publications Inc., 1983), 59. 
manusia harus belajar dari perilaku dan kebiasaan hewan-hewan, agar manusia yang memiliki akal budi dapat hidup lebih baik.

\section{Ayub 39:16-21 (Gambaran tentang burung Unta)}

Dalam bagian ini digambarkan bahwa gurung Unta adalah burung yang tidak indah dan tidak dapat terbang, tetapi ia memiliki kelebihan yaitu dapat berlari dengan cepat di atas tanah. Burung Unta juga tidak dapat bertelur di atas pohon, melainkan telurnya ditinggalkan di tanah dan dibiarkan menjadi panas di dalam pasir. Meskipun mungkin saja telur itu terpijak kaki dan diinjak oleh binatang-binatang liar, namun telur itu pada akhirnya akan menetas juga. Dalam memperlakukan anak-anaknya, burung Unta digambarkan sebagai "orang tua" yang keras mendidik dan ia tidak peduli kalau jerih payahnya sia-sia. Hal ini terjadi karena burung Unta tidak mendapat hikmat dari Allah.

Terhadap burung Unta ini berlaku pertanyaan retorika, "Apakah kepak dan bulu burung itu menaruh kasih sayang?"

Jawaban dari pertanyaan retorika itu terdapat dalam penjelasan Allah mengenai keberadaan burung Unta itu. Meskipun tampak seperti burung yang tidak berhikmat dan bahkan tidak peduli terhadap anaknya, tetapi burung Unta tetap mengarahkan anaknya untuk bisa bertahan dalam hidup. Kesengsaraan yang dialami oleh anak burung Unta, sejak ia berada di dalam telur yang ditinggalkan di atas tanah sampai pada pemberlakuan burung Unta terhadap anaknya dengan keras, mau menggambarkan bahwa sekeras apa pun didikan yang diberikan Allah kepada manusia, hal ini sebenarnya mau membentuk manusia untuk menjadi pribadi yang kuat dan mandiri.

Penderitaan adalah jalan untuk menuju pada pemahaman terhadap hidup dengan benar dan dalam. Sehingga penderitaan bukanlah peristiwa yang harus dihindari, tetapi harus dijalani dengan penuh penyerahan diri kepada "orang tua" yang mendidik anaknya dengan sangat keras. Penderitaan bukan untuk ditangisi, tetapi untuk dipakai menuju pada jenjang kedewasaan hidup yang berkualitas. 
Di sini mau ditegaskan bahwa penderitaan itu adalah bentuk lain dari kasih sayang Allah kepada Ayub. Melalui penderitaan, Allah mendidik Ayub untuk menjadi pribadi yang kuat dan terus berprinsip, meski harus menghadapi hal di luar keinginannya.

\section{Ayub 39:22-28 (Gambaran tentang Kuda)}

Bagian ini menggambarkan tentang kuda yang digunakan manusia untuk berperang untuk melawan musuhnya. Umumnya Perjanjian Lama menghadirkan sosok kuda sebagai tunggangan seorang kesatria ketika maju berperang (lih. Yos. 11:4; 2 Sam. 15:1). Dalam bagian ini Allah menggambarkan tentang kekuatan kuda; yang melingkupi:

1. Memiliki tenaga yang kuat dan dengan kekuatannya selalu maju menghadapi senjata.

2. Mampu melompat dan meringkik dengan dahsyat.

3. Dapat menggaruk tanah lembah.

4. Tidak pernah kecut hati bahkan selalu menertawakan kedahsyatan (lawan).

5. Pantang mundur dalam menghadapi pedang.

6. Kalau bunyi sangkakala terdengar, ia akan meronta-ronta.

7. Selalu bersemangat menghadapi setiap perang yang akan dilaluinya.

Terhadap gambaran tentang kuda ini, Allah memberikan pertanyaan retorika, "Engkaukah yang memberi tenaga pada kuda? Engkaukah yang mengenakan surai pada tengkuknya? Engkaukah yang membuat dia melompat sepert belalang?" Ketiga pertanyaan ini mewakili 3 jenis kekuatan yang dimiliki oleh kuda, yaitu: kekuatan (tenaga), keindahan (surai) dan kegagahan (melompat). Dengan ke-3 jenis kekuatan ini, kuda dipandang sebagai binatang yang layak dipakai untuk menghadapi perang. Dan Ayub digambarkan memiliki ketiga jenis kekuatan ini.

Gambaran tentang kuda yang kemudian dijadikan retorika oleh Allah, sebenarnya mau mengungkap keberadaan Ayub berada dalam naungan dan lindungan Allah saat penderitaan dan kesengsaraan datang, 
seperti halnya perang yang sedang dihadapi Ayub. Jawaban terhadap pertanyaan retorika ke-2 ini adalah terletak pada setiap gambaran kekuatan kuda yang diungkapkan oleh Allah.

Ayub adalah pribadi yang seharusnya lebih kuat dari pada kuda. Ia adalah pribadi yang harus berani menghadapi dan menjalani penderitaan akibat perang yang berkecamuk dalam kehidupannya. Bahkan Ayub pun harus bisa menertawakan kedahsyatan penderitaan itu, karena Ayub adalah pribadi yang dilindungi dan disertai oleh Allah; sehingga jangan pernah ada kata mundur dalam hidup Ayub saat sedang didera oleh penderitaan. Ayub harus terus bersemangat, karena biar bagaimana pun perang dan penderitaan itu akan berlalu

\section{Ayub 39:29 (Gambaran tentang Burung Elang)}

Dalam gambaran ini dijelaskan mengenai kuasa Allah yang memberikan kemampuan kepada burung Elang untuk bisa terbang. Jika dikatakan terbangnya burung Elang itu ke selatan, kemungkinan besar yang dimaksud daerah selatan adalah Negeb (yang berarti "yang kering"). Jadi terbangnya burung Elang itu adalah menuju pada tanah kering yang menantang, namun ia tetap dapat bertahan hidup dan tidak pernah kalah terhadap berbagai macam kering kerontangnya tanah di bagian selatan. Bahkan dengan kekuatan-Nya, Tuhan membimbing burung Elang untuk dapat menghadapi kegersangan tanah selatan.

Jika dalam bagian ini pertanyaan retorika Tuhan adalah, "Oleh pengertianmukah burung elang terbang, mengembangkan sayapnya ke selatan?" Maka yang mau ditegaskan di sini adalah bahwa Tuhan akan mampu membimbing Ayub untuk mengatasi masa-masa kekeringan dalam hidupnya. Ayub memang tidak bisa mengerti (dan tidak harus perlu mengerti) tentang apa yang dihadapinya. Tetapi jika ia mau mengandalkan Tuhan, maka Tuhan akan membimbing Ayub untuk terbang mengatasi segala penderitaan yang ada. Bersama Tuhan, Ayub akan berada di

${ }^{7}$ A. B. Davidson, The Theology of The Old Testament (Edinburgh: T\&T Clark, 1976), 492. 


\section{Prosiding Seminar Teologi Kitab Ayub}

atas dan mengatasi penderitaan. Bahkan penderitaan yang digambarkan sebagai tanah kering itu pun akan mampu dilewati.

\section{Ayub 39:30-33 (Gambaran tentang Burung Rajawali)}

Burung Rajawali adalah burung yang meletakkan sarangnya di tempat yang tinggi dan ia selalu terbang membubung tinggi. Karena sarang yang dibangun di atas tebing yang tinggi, maka anak-anak burung Rajawali tidak akan pernah mengalami gangguan dari binatang lain. Mata induk Rajawali begitu tajam, sehingga ia dapat mengintai mangsa dengan cermat dan kemudian menerkam mangsanya serta membawa mangsa tersebut ke anak-anaknya sebagai wujud pemeliharaan induk rajawali terhadap anak-anaknya. Atas gambaran ini, berlaku pertanyaan retorika, "Atas perintahmukah Rajawali terbang membubung, dan membuat sarangnya di tempat yang tinggi?" Atas pertanyaan ini, Tuhan memberi jawaban bahwa seperti induk Rajawali yang melindungi anaknya di tempat yang tinggi dan aman, maka demikian jugalah Tuhan akan melindungi Ayub. Bahkan Tuhan akan memelihara Ayub dengan menyediakan segala kebutuhan, baik dalam masalah makan, kenyamanan hidup (sarang) dan juga jaminan keselamatan. Karena Tuhanlah yang akan berjuang untuk melindungi Ayub, sehingga tidak akan ada satu pun kekuatan yang mampu memangsa Ayub.

Dari ke-4 gambaran tentang binatang yang dihadirkan Tuhan kepada Ayub, mau ditegaskan bahwa karya Tuhan dalam menjaga dan membela Ayub merupakan tindakan yang benar-benar mampu menyelamatkan Ayub dari penderitaan dan kesengsaraan. Inilah jawaban Tuhan terhadap pertanyaan dan pergumulan Ayub. Melalui jawaban ini akhirnya Ayub mengaku mengenal Tuhan berdasarkan pengertiannya sendiri (psl. 42:5).

\section{Implikasi Teologis}

Melalui gambaran-gambaran tentang binatang yang diikuti dengan pertanyaan retorika, maka perikop/bagian ini (Ayb. 39: 16-33) sebenarnya 
Analisis Pertanyaan Retorika Dalam Ayub 39:16-33

mau menghadirkan sosok Tuhan yang begitu Agung dan sekaligus yang tidak dapat dijangkau melalui pikiran. Kemahakuasaan Tuhan begitu besar dan mistetrius; tetapi bukan berarti tidak berdampak bagi kehidupan. Di dalam kebesaran dan kemisteriusan itulah karya Tuhan selalu mengiringi kehidupan manusia.

Dalam hal ini, manusia sedang berhadapan dengan sosok Raja yang memang sangat sakral; dan kesakralan Raja tersebut tidak dapat disentuh oleh manusia. Bahkan untuk mempertanyakan kesakralan Raja tersebut, manusia tidak berhak. Kesakralan Raja yang menentukan hidup manusia. Manusia hanya diminta untuk terus setia dalam mempertahankan keyakinannya pada kesakralan Raja tersebut. ${ }^{8}$ Karena dengan keyakinan tersebut, manusia akan senantiasa dapat mengatasi segala pergumulan dan penderitaan yang mendera manusia, meskipun kadangkala penderitaan itu tidak seharusnya diderita oleh manusia. Namun dengan berbekal kesetiaan pada kesakralan Raja, maka manusia akan mampu dan dimampukan untuk mengatasi segala pergumulan dan penderitaan hidup.

Gambaran-gambaran tentang hewan (burung Unta, Kuda, Elang dan Rajawali) merupakan gambaran yang mau menjelaskan bagaimana tangan Allah senantiasa melindungi Ayub dalam masa sengsaranya; dan bahkan menuntun Ayub untuk mengatasi segala penderitaannya. Karena itu, Ayub tidak berhak untuk menanya dan bahkan mempertanyakan kuasa Allah. Karena kuasa Allah tidak terbatas, serta tidak akan pernah bisa diselami oleh kemampuan berpikir manusia.

Di sinilah dibangun sebuah pemahaman Teologi Kemahakuasaan Allah. Dalam teologi Kemahakuasaan Allah, tidak ada kemungkinan bagi ketidakbersalahan manusia di hadapan Allah. Manusia pasti bersalah, dan Allah pasti tidak pernah bersalah. Manusia bersalah karena manusia tidak berkuasa, dan Allah tidak bersalah karena Allah berkuasa. Itu berarti kebenaran dipegang oleh pemegang dari kekuasaan itu, yaitu Allah. ${ }^{9}$ Karena itu, manusia jangan pernah mempertanyakan kekuasaan Allah

${ }^{8}$ Rene Girard, Ayub, Korban Masyarakatnya (Jakarta: BPK Gunung Mulia, 2003), 110-112.

${ }^{9}$ E. G. Singgih, 147. 


\section{Prosiding Seminar Teologi Kitab Ayub}

dan bahkan memberontaknya, karena kekuasaan Allah itu mutlak, meski pun kadang kala berjalan dalam misteri yang tidak bisa dipahami oleh manusia. Asalkan manusia mau mengakui kemahakuasaan Allah dan selalu berserah pada kemahakuasaan Allah, maka Allah akan berpihak pada manusia.

Dengan kata lain, jikalah manusia mempertanyakan kuasa Allah maka hal itu tidak menunjukkan iman dan penyerahan diri kepada Allah. Sikap mempertanyakan Allah berbeda dengan sikap bertanya kepada Allah. Mempertanyakan Allah adalah tindakan yang ingin campur tangan (intervensi) terhadap apa yang sudah dilakukan Allah. Tindakan ini tampak dalam pertanyaan, "Mengapa Allah melakukan hal ini kepadaku?" Dalam pertanyaan seperti ini, ada unsur mempersalahkan Allah dan juga ada keinginan untuk campur tangan terhadap apa yang sudah dilakukan oleh Allah. Juga dalam pertanyaan ini ada kesan untuk mengatur pekerjaan Allah agar selalu sesuai dengan apa yang diinginkan manusia. Inilah yang sebenarnya menghancurkan iman manusia kepada Allah,

Akan tetapi jika manusia bertanya kepada Allah, maka pertanyaan seperti itu justru menunjukkan kadar keimanan yang baik dalam diri manusia. Karena ketika manusia bertanya, "Mengapa hal ini terjadi pada diriku, Tuhan?", maka pertanyaan ini memiliki pengertian manusia sedang melakukan introspeksi (menilai ulang tentang keberadaan dirinya sendiri; melihat ke dalam). Dalam introspeksi tersebut manusia mengevaluasi tindakan dan kehidupannya, yang mungkin saja menyakiti hati Tuhan dan melakukan hal-hal yang di luar kehendak Tuhan. Tindakan ini merupakan tindakan iman; karena bukan menunjuk pada keegoisan diri (manarik segala hal di luar untuk kepentingan diri sendiri), melainkan merefleksikan apa yang sudah terjadi di dalam untuk ditarik keluar dalam menggapai kesadaran diri yang lebih dalam. Inilah iman yang murni.

\section{Implikasi Praktis}

Menghadapi teologi Kemahakuasaan Allah yang dibangun dalam perikop ini, maka ada beberapa implikasi praktis yang perlu dikembang- 
kan dalam kehidupan, antara lain:

1. Manusia harus menyadari sepenuhnya bahwa penyelenggara kehidupan adalah Allah. Melalui kesadaran tersebut, manusia selayaknya memiliki iman kepada Sang Penyelenggara hidup. Yang dimaksud dengan iman di sini bukan sekadar percaya, tetapi lebih daripada itu, yaitu mempercayakan diri (dari kata 'aman = memegang teguh) kepada Allah, sehingga terjadi penyerahan diri yang total kepada Yang Maha Kuasa.

2. Di satu sisi, manusia harus menyadari bahwa dirinya memiliki keterbatasan, sehingga ia senantiasa berada dalam posisi kebersalahan. Di sisi lain, ada sosok Allah yang memiliki ketidakbersalahan karena keberadaan-Nya tidak terbatas. Oleh sebab itu, perlu ada pengakuan yang tulus dalam diri manusia untuk menempatkan pengharapan dan kepercayaannya kepada yang Tidak Terbatas tersebut. Sehingga ada jaminan perlindungan mutlak terhadap kehidupan manusia.

3. Allah adalah sosok yang benar dan tidak layak untuk dipertanyakan, sehingga sikap yang harus ditumbuhkan manusia haruslah mengakui ketidak-dapat-bersalahan Allah.

4. Sikap yang mengandalkan Kemahakuasaan Allah akan menghantar manusia pada perasaan nyaman di dalam perlindungan Allah.

5. Meski manusia mengalami penderitaan dan kesengsaraan akibat hal yang tidak pernah diketahui, yang dipentingkan dalam menghadapi peristiwa itu adalah tetap setia kepada Allah. Karena melalui sikap setia kepada Allah, manusia akan mampu masuk ke dalam misteri kasih Allah yang pada dasarnya akan menyelamatkan hidup manusia. Karena Allah sudah menjamin kehidupan manusia yang mau bersandar pada-Nya.

\section{Kepustakaan}

Bullock, C. Hassel. Introduction to The Old Testament Poetic Book. Chicago: The Moody Bible Institute, 1979.

Davidson, A. B. The Theology of The Old Testament. Edinburgh: T\&T 
Clark, 1976.

Davidson, Benjamin. The Analytical Hebrew and Chaldee Lexicon. Michigan: Regency Reference Library, 1970.

Girard, Rene. Ayub, Korban Masyarakatnya. Jakarta: BPK Gunung Mulia, 2003.

Harlow, R. E. Job Had A Problem. Canada: Everyday Publications Inc., 1983.

Singgih, E. G. Dua Konteks. Jakarta: BPK Gunung Mulia, 2009.

Wahono, Wismoady. Di Sini Kutemukan. Jakarta: BPK Gunung Mulia, 1987. 